Discussion Paper No. 08-099

\title{
Ex Post Regulation Facilitates Collusion
}

Patrick Beschorner

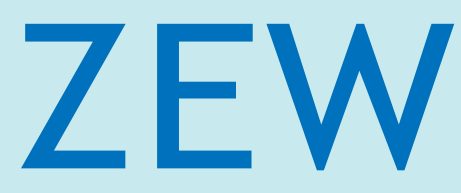

Zentrum für Europäische Wirtschaftsforschung $\mathrm{GmbH}$

Centre for European

Economic Research 
Discussion Paper No. 08-099

\title{
Ex Post Regulation Facilitates Collusion
}

\author{
Patrick Beschorner
}

Download this ZEW Discussion Paper from our ftp server:

\begin{abstract}
ftp://ftp.zew.de/pub/zew-docs/dp/dp08099.pdf
\end{abstract}
Die Discussion Papers dienen einer möglichst schnellen Verbreitung von neueren Forschungsarbeiten des ZEW. Die Beiträge liegen in alleiniger Verantwortung der Autoren und stellen nicht notwendigerweise die Meinung des ZEW dar.

Discussion Papers are intended to make results of ZEW research promptly available to other economists in order to encourage discussion and suggestions for revisions. The authors are solely responsible for the contents which do not necessarily represent the opinion of the ZEW. 


\section{Non-technical Summary}

Deregulation and privatization of public utilities in grid-based industries raises the question on how to provide an efficient access to the network infrastructure to entering service providers. Often the incumbent firm which controls the grid is also active on the service market which requires access to the network and where it is competing with entering firms. Balancing the efficiency of service provision and the incentive to invest in the network infrastructure suffers a lack of information and creates a range of discretion to the regulator. Typically, the regulator has to mediate the conflict between the incumbent, which demands a high access fee, and the service entering providers, which complain about excessive access fees.

The present analysis indicates for markets in which quality competition is essential that a vertically integrated incumbent benefits from a high access fee. Both the revenue from the access fees and preventing tough price competition are beneficial effects to the incumbent. Entrants will recognize that the access fee is above marginal cost and this gives rise to complaints and requests for reviews of the access rate by the regulatory body.

However, if there is a single entrant which is protected from further entry the two active firms may agree upon an access fee that is higher than the marginal cost, which would be the efficient level. The reason is that the higher access fee serves as a commitment device to not engage in tough price competition. Therefore, the incumbent is also willing to raise its price, which results in higher revenue. In this situation a regulator does not face conflicting arguments by the incumbent and the entrant and, under ex post regulation, may not be alerted to review the level of the access fee. 


\section{Zusammenfassung}

Die Deregulierung und Privatisierung öffentlicher Versorgungsunternehmen wirft in netzgebundenen Industrien die Frage auf, wie der effiziente Zugang zum Netzwerk durch Wettbewerber auf dem Dienstleistungsmarkt gewährleistet werden kann. Oft wird das Netzwerk von einem Unternehmen kontrolliert, das zugleich Dienste unter Nutzung des Netzes erbringt und auf diesem Markt mit neuen Unternehmen in Konkurrenz steht. Der effizienten Bereitstellung der Dienstleistungen durch eine niedrige Zugangsgebühr steht entgegen, dass der Netzwerkbetreiber ein Anreiz haben muss, das Netzwerk zu unterhalten und auszubauen. Typischerweise, muss der Regulierer in dem Konflikt zwischen dem Netzbetreiber, der einen hohen Zugangspreis bevorzugt, und den Diensteerbringern, die überzogene Zugangspreise monieren, vermitteln.

Diese Untersuchung zeigt für einen Markt, in dem Qualitätswettbewerb vorherrscht, dass der Netzwerkbetreiber, der auch auf dem Servicemarkt tätig ist, einen Anreiz hat, eine ineffizient hohe Zugangsgebühr zu verlangen. Er profitiert dann sowohl vom dem Erlös aus der Zugangsgebühr, als auch von dem anbeschwächten Wettbewerb auf dem Servicemarkt. Die neuen Unternehmen stellen fest, dass die Zugangsgebühr über den Grenzkosten liegt und verlangen eine Überprüfung dieser Gebühr durch die Regulierungsbehörde.

Wenn hingegen das eintretende Unternehmen keinen weiteren Marktzutritt zu befürchten hat, vereinbaren die beiden aktiven Unternehmen eine Zutrittsgebühr, die über dem effizienten Maß liegt, das den Grenzkosten entsprechen würde. Der Grund liegt darin, dass eine hohe Zugangsgebühr den Preiswettbewerb durch das eintretende Unternehmen unterbindet. In der Folge kann das etablierte Unternehmen seinen Preis erhöhen und einen höheren Erlös erzielen. In einer solchen Situation erhebt das neue Unternehmen nicht den Vorwurf einer exzessiven Zugangsgebühr. Unter einer ex post Regulierung, bei der der Regulierer erst einschreitet, wenn die Unternehmen keine Einigung erzielen, kann eine ineffizient hohe Zugangsgebühr unbemerkt bleiben. 


\title{
Ex Post Regulation Facilitates Collusion
}

\author{
Patrick F.E. Beschorner*
}

December 4, 2008

\begin{abstract}
Under ex ante access regulation entrants often claim that access fees are excessive. I show that this is only the case if further entry is admitted. If the entrant is protected from further entry it would agree with the incumbent upon a strictly positive access fee which may exceed the efficient level. Ex post regulation facilitates this type of collusion and should be abandoned.
\end{abstract}

Keywords: entry deterrence, access regulation, network infrastructure, vertical differentiation

JEL: K21, K23, L42, L51

* ZEW Centre for European Economic Research, Mannheim, P.O.Box 103443 68034 Mannheim, Germany, tel. +49-(0)621-1235-175, fax. +49-(0)621-1235-170, beschorner@zew.de. I would like to thank Jeanine Miklós-Thal for her helpful suggestions and comments. This paper was written while I was a visiting researcher at U.C. Berkeley. I thank the Department of Economics and Prof. Bronwyn Hall for their hospitality. Financial Support from the Deutsche Forschungsgemeinschaft through SFB/TR15 and from RNIC Research Network on Innovation and Competition Policy is gratefully acknowledged. 


\section{Introduction}

Following the liberalization of formerly publicly provided utilities, e.g. telecommunications and electricity, often access regulation has been set up where competing service providers rely on access to the infrastructure which is an essential facility and which constitutes a natural monopoly (Hellwig (2008)). Under ex ante regulation a regulation authority imposes an access fee for service providers who are connecting to the incumbent's network. Ex post regulation relegates this process to after the incumbent and the entrant(s) have or have not come to an agreement. The regulator has to balance the beneficial effect of downstream competition on the service market against the network provider's incentive to maintain and enhance the network infrastructure. It is beyond the scope of this article that to some extent access regulation is a negotiation process involving the incumbent network provider, entering firms, and the regulation authority such that is adopts traits of collusion and price control (Rey (2003)).

The model relies on previous research by Gabszewicz and Thisse (1979) and Gabszewicz (1980) on consumer choice under vertical differentiation products, Shaked and Sutton (SS) $(1982,1983)$ providing the foundation of a natural oligopoly in markets with vertically differentiated products, sequential entry (Hung and Schmitt (HS) (1988), and quality dependent costs (Lutz (1997)).

I go beyond this literature in analyzing the potential for collusion under ex ante and ex post access regulation with (limited) entry in a market with vertical product differentiation. Section 2 presents a simple model of vertical differentiation, which is analyzed in section 3. Section 4 provides a discussion of the results: Ex post regulation creates an incentive to collude with respect to the access fee, free entry prevents incentive for such collusion, and access should be facilitated.

\section{Model}

Consumers, which have unit mass, differ by their uniformly distributed income $m$ on the interval $[a, b]$. Their utility is defined by $U(m, t)=m \cdot t$ where $t \in[\underline{t} ; \bar{t}]$ is the quality of the product of which they purchase exactly 
one unit or none at price $p .{ }^{1}$ The price of the reservation quality is zero. $y_{1}=\left(p_{1} t_{1}-p_{2} t_{2}\right) /\left(t_{1}-t_{2}\right)$ defines the consumer who is indifferent between quality and price $\left(t_{1}, p_{1}\right)$ and $\left(t_{2}, p_{2}\right)$ where $t_{1}$ and $t_{2}$ are the qualities of the two products. For the analysis I assume $t_{1}>t_{2}$ and I will show later that firm 2 prevents the entrant's offering superior quality. Consumers $y>y_{1}$ prefer 1 over 2. Similarly, $y_{2}=p_{2} t_{2} /\left(t_{2}-\underline{t}\right)$ is indifferent between $(\underline{t}, 0)$ and $\left(t_{1}, p_{1}\right)$. Further, assume $a<y_{2}<y_{1}<b$. An entering firm bears sunk cost $f>0$ and a per unit access fee $c$ payable to the incumbent. The firms' profits are given by

$$
\begin{aligned}
& \pi_{1}=p_{1}\left(b-y_{1}\right)+\left(y_{1}-a\right) c \\
& \pi_{2}=\left(p_{2}-c\right)\left(y_{1}-a\right)-f .
\end{aligned}
$$

The sequence of the game is as follows: The incumbent decides upon $c$ before entry occurs. We will see that at most one firm enters the market in the case where further entry would be admissible. Then, the incumbent sets his quality before the entrant and finally both firms compete in prices simultaneously. We solve for the subgame perfect equilibrium.

The equilibrium prices after the firms have set $t_{1}$ and $t_{2}$ in the previous stage are

$$
\begin{aligned}
& p_{1}=A\left(1-\frac{t_{2}}{t_{1}}\right)+\frac{2 t_{1}+t_{2}}{3 t_{1}} c \\
& p_{2}=B\left(\frac{t_{1}}{t_{2}}-1\right)+\frac{t_{1}+2 t_{2}}{3 t_{2}} c
\end{aligned}
$$

where

$$
A=\frac{2 b-a-c}{3} \quad ; \quad B=\frac{b-2 a+c}{3}
$$

and the payoffs resulting from the price stage are

$$
\begin{aligned}
& \pi_{1}=A^{2}\left(1-\frac{t_{2}}{t_{1}}\right)+c(b-a) \\
& \pi_{2}=B^{2}\left(\frac{t_{1}}{t_{2}}-1\right)-f .
\end{aligned}
$$

\footnotetext{
${ }^{1}$ This utility function has the property that consumers differ in their valuation for quality according to their wealth or in come. It has been employed in all six papers listed as previous research.
} 


\section{Analysis}

Relying on the result by SS that at most two firms can be profitably active under vertical differentiation I show that the incumbent has an incentive to raise the access fee and the entry cost. Further, a higher entry cost results in a higher degree of product differentiation, thus approaching the same degree of product differentiation as under free entry, but with higher prices. I start with the analysis of free entry, which is analogous to HS before considering protected entry.

\subsection{Free Entry}

Lemma 1 of HS states that for $2 a<b<4 a$ there are at most two firms having positive market share and covering the entire market with goods of distinct qualities. To ensure that it is active on the market the entrant chooses its quality

$$
t_{2}=t_{1} \cdot \frac{B^{2}}{B^{2}+f}
$$

such that $\pi_{2}\left(t_{1}, t_{2}\right)=0$ in order to prevent further entry. If it earned strictly positive profit, a third party could offer $\left(t_{2}-\varepsilon, p_{2}\right)$ and drive it out of the market.

The incumbent prevents leapfrogging by the entrant, i.e. the latter does not offer higher quality than the incumbent. By choosing $t_{1}>\theta^{\prime}$ the entrant cannot earn positive profit even when offering the highest quality. The condition

$$
A^{2} \cdot\left(1-\frac{t_{1}}{\bar{t}}\right)-f<0
$$

transforms into

$$
t_{1}>\left(1-\frac{f}{A^{2}}\right) \cdot \bar{t} \equiv \theta^{\prime} .
$$

Observing (5), the entrant sets $t_{2}$. It covers its fixed cost $f$ as long as

$$
t_{1}>\left(\frac{f}{B^{2}-1}\right) \cdot \underline{t} \equiv \theta^{\prime \prime} .
$$


If $\theta^{\prime \prime}>\theta^{\prime}$ there is no leapfrogging and the entrant earns negative profit. Otherwise, entry is accommodated according to Lemma 2 in HS.

Now, I analyze the incumbent's incentive to set $c$. The proportionality of $t_{2}$ and $t_{1}$ implies that (3) is not affected by the choice of $c$ when $c=0$, such that the incumbent is indifferent between all $t_{1} \in\left[\max \left(\theta^{\prime}, \theta^{\prime \prime}\right), \bar{t}\right]$, which follows from Proposition 1 of HS. Inserting (5) into (3) yields

$$
\pi_{1}=\frac{A^{2} f}{B^{2}+f}+c(b-a)=\frac{(2 b-a-c)^{2} f}{b-2 a+c)^{2}+9 f}+c(b-a) .
$$

Proposition 1 The incumbent's profit is increasing in the access fee $c$ and the entry cost $f$.

Proof. $\partial \pi_{1} / \partial c>0$ and $\partial \pi_{1} / \partial f>0$ are shown in the appendix.

Remark 1 The access fee increases the entrant's price. This relaxes price competition, thus allowing for both prices to rise (See (1), (2)).

Remark 2 The access fee drives $t_{2}$ towards $t_{1}$, but this effect is mitigated by:

Remark 3 An increase in $f$ forces $t_{2}$ to stronger differentiate from $t_{1}$ (See (5)).

\section{$3.2 \quad$ Protected Entrant}

The firms maximally differentiate, $t_{1}=\bar{t}$ and $t_{2}=\underline{t}$ in order to relax competition. This follows immediately from firm 1 and 2 maximizing profits (3) and (4) with respect to $t_{1}$ and $t_{2}$, respectively. This result is in line with SS and HS. This effect is mitigated as quality dependent costs reduce the incentive to offer the maximum quality (Lutz (1997)).

Lemma 1 The incumbent benefits from a high access fee.

Proof. Inserting $t_{1}=\bar{t}$ and $t_{2}=\underline{t}$ into (3) results in $\pi_{1}=A^{2} \cdot d+c(b-a)$ where $d=(\bar{t}-\underline{t}) / \bar{t}$.

$$
\frac{\partial \pi_{1}}{\partial c}=\frac{5 b-7 a+2 c}{9}+\frac{4 b-2 a-2 c}{9} \cdot \frac{t}{\bar{t}}>0 .
$$


Lemma 2 The entrant benefits from a high access fee.

Proof. $\partial \pi_{2} / \partial c>0$ follows immediately from inserting $d$ into (4).

Remark 1 The entrant's price is rising in $c$. This is technically limited by the assumption $y_{2}<y_{1}<b$. For $c=2 b-a$ the incumbent has no sales, but has revenue purely from access fees $c(b-a)$.

Remark 2 The effect of the access fee on the incumbent's price is ambiguous, because a rise in $p_{2}$ relaxes price competition while a rise in $p_{1}$ lowers overall demand.

Remark 3 The positive access fee serves as a commitment for the entrant not to lower its price.

Proposition 2 Both firms will agree upon a strictly positive access fee.

Proof. This follows immediately from the two Lemmata.

\section{Policy Implications}

The model advocates ex ante access regulation because ex post regulation creates incentives for excessive access fees. An entrant tends to mandate a review of an allegedly excessive access fee if it faces potential competition. Otherwise, if further entry is inhibited, it is willing to agree upon a strictly positive access fee and any such fee necessarily exceeds the marginal cost which is normalized to zero in this model. Consequently, ex post regulation is ineffective for inhibiting this form of collusion. Thus, ex post regulation may delay the regulator's setting an efficient access fee when quality is the prevalent dimension of competition. This effect is amplified because balancing the efficiency of the service provision and the incentive to invest in the network infrastructure opens a range of discretion to the regulator.

Moreover, the regulator has to enforce free access by entrants to and compatibility with the network. The fixed entry costs are due to technical issues on interconnection and compatibility, which are to some extent subject to the incumbent's discretion. They constitute a sunk investment and provide 
to the incumbent a subtle instrument to afflict service competition. Thus, the incumbent may hinder compatibility in order to prevent entry through narrowing the parameter ranges where he accommodates entry. 


\section{References}

Hung, N.M., Nicolas Schmitt (1988), Quality Competition and Threat of Entry in Duopoly, in: Economics Letters 27, 287-292.

Gabszewicz, Jean Jaskold (1980), Entry (and exit) in a differentiated industry, Journal of Economic Theory 22, 327-338.

Gabszewicz, Jean Jaskold and Jacques-François Thisse (1979), Price competition and income disparities, Journal of Economic Theory 20, 340-359.

Hellwig, Martin (2003), Competition Policy and Sector-Specific Regulation for Network Industries, Preprints of the Max Planck Institute for Research on Collective Goods No.209.

Lutz, Stefan (1997), Vertical Product Differentiation and Entry Deterrence, in: Journal of Economics 65(1), 79-102.

Shaked, Avner and John Sutton (1982), Relaxing Price Competition Through Product Differentiation, in: Review of Economic Studies 49, 3-13.

Shaked, Avner and John Sutton (1983), Natural Oligopolies, in: Econometrica $\mathbf{5 1}, 5, \mathbf{1 4 6 9 - 1 4 8 3 .}$

Rey, Patrick (2003), Towards a Theory of Competition Policy, in: Advances in M. Dewatripont, L. P. Hansen and S. J. Turnovsky (eds.), Economics and Econometrics: Theory and Applications - Eight World Congress, Series Econometric Society Monographs, Vol.II, No.36, Cambridge University Press, 82-132. 


\section{Appendix}

\section{Proof of Proposition 1}

$$
\frac{\partial \pi_{1}}{\partial c}=\frac{-2 f(2 b-a-c)[(b-2 a+c)(3 b-3 a)+9 f]}{\left[(b-2 a+c)^{2}+9 f\right]^{2}}
$$

Inserting the smallest admissible value for $b=2 a$ yields

$$
\frac{-2 f(3 a-c)[3 c a+9 f]}{\left[(b-2 a+c)^{2}+9 f\right]^{2}}+a
$$

and $a / 3>0$ for $c=0$.

$$
\frac{\partial \pi_{1}}{\partial f}=\frac{(2 b-a-b)^{2}(b-2 a+c)^{2}}{\left[(b-2 a+c)^{2}+9 f\right]^{2}}>0 .
$$

